\title{
THE ASSOCIATION BETWEEN ADULT DRUG ABUSE AND CHILDHOOD MALTREATMENT IN STUDENTS ATTENDING SEVEN UNIVERSITIES IN FIVE COUNTRIES IN LATIN AMERICA AND ONE COUNTRY IN THE CARIBBEAN
}

\author{
Samantha Longman-Mills ${ }^{1}$, Yolanda Maria González Williams², Marlon Osman Melendez Rodriguez ${ }^{3}$, Monica \\ Rosaura García Baquero ${ }^{4}$, Juan Daniel Gómez Rojas ${ }^{5}$, Cristina Juárez de Amaya ${ }^{6}$, Eduardo Alfredo Martínez \\ Diaz ${ }^{7}$, Sobeya Jose Peñalba Corea ${ }^{8}$, Enrique Miguel Pizzanelli Baez ${ }^{9}$, Lucia Isabel Solórzano Tinoco ${ }^{10}$
}

${ }^{1}$ Ph.D. Associate Professor, Faculty of Medical Sciences, University of the West Indies. Mona Campus. Kingston, Jamaica. E-mail: samantha.longman02@uwimona.edu.jm

2 Ph.D. Associate Professor, School of Nursing, University of Panama. Panama City, Panama. E-mail: yolamari22@yahoo.com

${ }_{3}^{3}$ M.Sc. Former Faculty, Universidad Nacional Autónoma de Nicaragua. León, Nicaragua. E-mail: marlonmelendezrodriguez@ yahoo.com

4 M.Sc. Nurse, Assistant Professor, School of Nursing, Universidad de los Llanos. Villavicencio, Colombia. E-mail: mgbaquero@ gmail.com

5 Ph.D. Full Professor, School of Psychology, Pontificia Universidad Javeriana. Bogotá, Colombia. E-mail: jd,gomez@javeriana. edu.co

${ }^{6}$ Doctoral Student. Dean School of Medicine, Universidad Evangélica de El Salvador. San Salvador, El Salvador. E-mail: cjuarez9007@yahoo.com

7 M.Sc. Former Assistant Professor, School of Medicine, Universidad Evangélica de El Salvador. San Salvador, El Salvador. E-mail: eamd73@gmail.com

8 M.Sc. Assistant Professor, School of Education, Universidad Nacional Autónoma de Nicaragua, León, Nicaragua. E-mail: spenalba2005@yahoo.es

${ }^{9}$ M.Sc. Assistant Professor, School of Medicine, Universdad de la República Oriental del Uruguay, Montevideo, Uruguay. E-mail: miguelpizzanelli@yahoo.com

${ }^{10}$ M.Sc. Former Faculty, School of Psychology, Universidad Nacional Autónoma de Nicaragua, UNAN-León, León, Nicaragua. E-mail:lucytinoco@gmail.com

\begin{abstract}
This study investigated the relationship between childhood maltreatment and adulthood drug abuse among university students from seven universities in five countries in Latin America and one country in the Caribbean. This multi-country study utilised a cross-sectional design to collect data on drug abuse, as well as retrospective data on maltreatment during childhood. The sample consisted of 2,283 university students, of which $82.6 \%$ reported childhood maltreatment experiences, and $33.5 \%$ increased levels of psychological distress. A significant relationship was observed between childhood maltreatment and drug abuse as an adult ( $p<0.05$ ). Although the sampling technique does not permit generalisations to all university students, the current study identified exposure to childhood maltreatment as a potential precursor to adult drug abuse within the populations studied. Therefore, the effectiveness of drug demand reduction strategies at the respective universities may be enhanced by incorporating policies and interventions aimed at childhood maltreatment.
\end{abstract}

DESCRIPTORS: Child abuse. Latin America. Substance-related disorders. Students. Universities.

\section{A ASSOCIACAO ENTRE O ABUSO DE DROGAS E O MALTRATO INFANTIL EM ESTUDANTES DE SETE UNIVERSIDADES DE CINCO PAISES DA AMÉRICA LATINA E UM DO CARIBE}

RESUMO: Este estudo busca identificar a relação entre o maltrato durante a infância e o abuso de drogas entre estudantes de sete universidades em cinco países de America Latina e um país do Caribe. Este é um estudo feito em vários países, utilizando um desenho de corte para coletar os dados de abuso de drogas e um levantamento retrospectivo sobre o maltrato na infância. A amostra foi constituída de 2.283 estudantes universitários, dos quais 82,6\% informaram terem sido maltratadas na infância e 33,5\% informaram ter níveis elevados de distresse psicológicos. Os dados indicaram uma relação significante $(p<0.05)$ entre maltrato na infância e o abuso de drogas na vida adulta. Apesar da técnica amostral não permitir generalização para a população de estudantes, universitários, o presente estudo identificou que a exposição ao maltrato durante a infância e um precursor potencial para o abuso de drogas na vida adulta nesta população. Portanto, estratégias para reduzir o consumo de drogas entre as respectivas universidades podem melhorar sua efetividade se incorporarem políticas e intervenções que levam em consideração o aspecto de maltrato na infância.

DESCRITORES: Maus-tratos infantis. America Latina. Transtornos relacionados ao uso de substâncias. Estudantes. Universidades. 


\title{
LA ASOCIACION ENTRE EL ABUSO DE DROGAS Y EL MALTRATO INFANTIL EN ESTUDIANTES DE SIETE UNIERSIDADES DE CINCO PAISES DE LATIN AMERICA Y UNO PAIS DEL CARIBE
}

\begin{abstract}
RESUMEN: Este estudio busca identificar la relación entre el maltrato durante la infancia y el abuso de drogas entre estudiantes de siete Universidad en cinco países de Latin America y uno país del Caribe. Este es un estudio hecho en varios países utilizando un diseño de corte para colectar los datos del abuso de drogas y un levantamiento retrospectivo sobre el maltrato en la infancia. La muestra fue constituida de 2.283 estudiantes universitarios, de los cuales 82,6\% informaran maltrato en la infancia, y 33,5\% informaran ter niveles elevados de distress psicológicos. Los datos indicaran una relación significante $(p<0.05)$ entre el maltrato en la infancia y el abuso de drogas en la vida adulta. A pesar de la técnica amuéstrale no permitir generalización para la población de estudiantes universitarios, el presente estudio identifico que la exposición al maltrato durante la infancia es un precursor potencial para el abuso de drogas durante la vida adulta. Por lo tanto, estrategias para reducir el consume de drogas entre las respectivas universidades poden mejorar su efectividad si incorporan políticas e intervenciones que llevan en consideración el aspecto del maltrato en la infancia.
\end{abstract}

DESCRIPTORES: Maltrato a los niños. Latin America. Trastornos relacionados con substancia. Estudiantes. Universidades.

\section{INTRODUCTION}

The production and consumption of licit and illicit drugs are of significant concern in Latin American and Caribbean countries. ${ }^{1}$ As a response, a number of prevention, treatment, and enforcement strategies have been implemented to reduce the supply and demand within this region. These interventions included use prevention campaigns, strict legal sanctions for participation in illicit drug trade, special enforcement units to prosecute drug traffickers, establishing alternate means of income for drug farmers, and the national funding of rehabilitation centres. To this end, millions of dollars have been spent on prevention strategies that have yielded limited success, as the region remains the world's largest producers of cocaine. ${ }^{2}$

The limited effectiveness of prevention strategies within Latin America and the Caribbean has highlighted the need to examine this region more closely, and identify potential risk factors of drug use and abuse. Research to date has established an association between childhood maltreatment and drug abuse during adulthood. However, this area of study has been limited to developed nations and, consequently, cases in Latin America and the Caribbean remain overlooked. ${ }^{3-8}$

Child maltreatment refers to acts of commission or omission with the potential to harm a child. ${ }^{9}$ These acts may include physical and emotional neglect, as well as physical, sexual, and verbal abuse. Many adverse outcomes are associated with childhood maltreatment, including developmental impairment resulting in cognitive, emotional, behavioural, and social problems. ${ }^{10}$ Furthermore, maltreated children often experience greater levels of psychological distress, and are therefore more likely to be diagnosed with a psychological disorder. ${ }^{11}$ These individuals may engage in drug abuse as a means of coping with said psychological distress. ${ }^{12}$

Rates of child maltreatment are particularly significant within Latin American and Caribbean cultures, as authoritarian parenting styles remain a common practice within this region. Despite the implementation of child-protection laws, it is estimated that more than 40 million children under the age of 15 currently experience some form of maltreatment. ${ }^{13}$ This number is reflected further in the extensive rates of maltreatment exhibited within individual countries: in Colombia, approximately 361 of every 1,000 children are maltreated annually; ${ }^{14-15}$ in El Salvador, a 2008 national study identified that $42 \%$ of female and $62 \%$ of male adults had experienced severe physical punishment during childhood; ${ }^{16}$ in Jamaica, 25,023 cases of child maltreatment were reported between 2007 and 2011;17 in Nicaragua, $54 \%$ of all children are estimated to be physically or verbally maltreated. Of these, $48 \%$ experience serious physical injuries, and 15\% sexual abuse; ${ }^{18}$ in Panama, the Committee for Children's Rights received 1,465 reports of child abuse in 2002, with a 38\% increase in cases between 2003 and 2006; ${ }^{19}$ and in Uruguay, a 2008 national study revealed that $86 \%$ of minors had experienced neglect, and $80 \%$ physical or psychological abuse. ${ }^{20}$

In light of these dramatic rates, the Inter-American Drug Abuse Control Commission (CICAD), the Centre for Addiction and Mental Health (CAMH), and the Government of Canada's Department of Foreign Affairs, Trade and Development (DFATD), provided essential support for a multi-centric study. This multi-university study investigated the relationship between childhood maltreatment, subsequent psychological distress, and rates of drug abuse during adulthood. 


\section{METHODOLOGY}

A cross-sectional survey design was used to collect retrospective data from 2,283 students attending seven universities within Colombia (2), El Salvador, Jamaica, Nicaragua, Panama and Uruguay. In each country, the sample frame was either the selected university or a faculty. Cases in which the entire university was sampled divided the faculties and randomly selected respective courses. Students who were enrolled in the selected courses and met the minimum age criterion of 18 years were invited to participate.

Alternatively, cases in which only one faculty was sampled employed a random selection of respective courses, with students enrolled in each solicited for participation. Courses were randomly selected until the desired sample size for each institution was achieved. Power analysis was utilised to determine the desired sample sizes for each university, with a sampling error of $5 \%$. This predefined random sampling technique was used for all but two institutions, for which systematic sampling and convenience sampling were used.

Data were collected using a 60-item questionnaire, which took approximately 35 minutes to complete. The questionnaire consisted of three main instruments - the Adverse Childhood Experiences questionnaire (ACE), ${ }^{21}$ the Kessler Psychological Distress Scale (K10), ${ }^{22}$ and select questions from the CICAD drug use questionnaire. ${ }^{23}$ The questionnaire was translated into Spanish and pilot-tested in each country to ensure cultural validity prior to its use.

The Adverse Childhood Experiences (ACE) questionnaire provides a measure of reported incidents of neglect, as well as sexual, verbal, and physical abuse, and has demonstrated adequate reliability and validity across international and cultural settings. ${ }^{24}$ Due to cultural sensitivities, two minor amendments were made to two questions for its use within Latin America and the Caribbean. In each case, the terms "oral, anal or vaginal", as used in questions pertaining to sexual abuse, were replaced with "any type of sexual intercourse."

The Kessler Psychological Distress Scale $(\mathrm{K} 10)^{22}$ provides a measure of psychological distress, which indicates the likelihood of being diagnosed with a psychological disorder. ${ }^{25}$ It is a 10-item survey, each with five possible responses, and is widely used by the World Health Organisation (WHO) for multi-national mental health surveys.
Six questions were selected and adapted from the CICAD drug use and abuse questionnaire ${ }^{23}$ as a measure of psychoactive drug use/ abuse among participants and their peers, as per the DSM-IV. The validity of the selected questions has been previously demonstrated among Latin American and Caribbean populations.

Using think-aloud interviews, the questionnaire was pilot-tested in each country to ensure that the items were interpreted as intended. As noted, the predefined random sampling technique was used in all but two institutions. Students were solicited to participate while on campus, either during class time, or within the vicinity of the selected faculty. Those selected to participate signed an informed consent form prior to completing the questionnaire.

The study was approved by the CAMH Ethical Committee on Nov. 2010, and by the Ethical Committee of each participant university between January-May 2011.

\section{RESULTS}

The sample consisted of 935 males and 1,348 females $(n=2,283)$, with a mean age of 20.63 years $(\mathrm{SD}=19)$. The majority of students $(59.5 \%)$ reported a middle-class socioeconomic status, and $74.1 \%$ of all students were raised in an urban setting. Religious beliefs were of importance among $72.8 \%$ of the participants, $62 \%$ of which were female.

\section{Childhood maltreatment experiences}

Maltreatment experiences were reported by $80.8 \%$ of males and $83.8 \%$ of females (see Table 1 ). The most frequent form was neglect $(83.8 \%)$, while approximately one third $(33.9 \%)$ reported incidents of physical abuse, and $30.4 \%$ of verbal abuse. Sexual abuse was the least reported form of maltreatment across all countries, at an overall rate of $6.1 \%$.

Table 1 - Reported experiences of childhood maltreatment, by Gender, 2011

\begin{tabular}{|c|c|c|c|c|c|c|}
\hline \multirow{2}{*}{$\begin{array}{c}\text { Type of } \\
\text { Maltreatment }\end{array}$} & \multicolumn{2}{|c|}{ Males } & \multicolumn{2}{|c|}{ Females } & \multicolumn{2}{|c|}{ Total } \\
\hline & $(f)$ & $(\%)$ & $(f)$ & $(\%)$ & $(f)$ & $(\%)$ \\
\hline Sexual abuse ${ }^{*}$ & 28 & 3.0 & 111 & 8.3 & 139 & 6.1 \\
\hline Physical abuse $^{\dagger}$ & 329 & 35.1 & 449 & 33.3 & 778 & 33.9 \\
\hline Verbal abuse f $^{\ddagger}$ & 267 & 28.5 & 435 & 32.3 & 702 & 30.4 \\
\hline Overall neglect ${ }^{\S}$ & 617 & 65.8 & 905 & 67.0 & 1,522 & 66.5 \\
\hline Any maltreatment ${ }^{\mid l}$ & 755 & 80.8 & 1,123 & 83.8 & 1,878 & 82.6 \\
\hline
\end{tabular}


Neglect was also the most frequently reported form of maltreatment in each individual country, with the exceptions of Jamaica and El
Salvador (see Table 2). In Jamaica, verbal abuse was most frequently reported, while both verbal and physical were most frequent in El Salvador.

Table 2 - Reported frequency of maltreatment, by Country, 2011

\begin{tabular}{|c|c|c|c|c|c|}
\hline \multirow[b]{2}{*}{ Country } & \multicolumn{5}{|c|}{ Maltreatment } \\
\hline & $\begin{array}{c}\text { Sexual abuse } \\
f(\%)\end{array}$ & $\begin{array}{c}\text { Physical abuse } \\
f(\%)\end{array}$ & $\begin{array}{c}\text { Verbal abuse } \\
f(\%)\end{array}$ & $\begin{array}{c}\text { Overall neglect } \\
f(\%)\end{array}$ & $\begin{array}{c}\text { Any maltreatment } \\
f(\%)\end{array}$ \\
\hline Colombia* $^{*}$ & $18(2.9)$ & $161(26.2)$ & $124(20.1)$ & $360(58.4)$ & $446(72.4)$ \\
\hline Jamaica $^{\dagger}$ & $51(13.4)$ & $236(61.8)$ & $247(64.7)$ & $107(28)$ & $303(79.3)$ \\
\hline Nicaragua $^{\ddagger}$ & $31(8.6)$ & $140(38.9)$ & $141(39.2)$ & $358(99.4)$ & $360(100)$ \\
\hline El Salvador ${ }^{\S}$ & $17(6.3)$ & $66(24.5)$ & $66(24.5)$ & 37 (13.8) & $116(43.1)$ \\
\hline Panamal| & $16(4.2)$ & 119 (31.6) & $81(21.5)$ & 373 (98.9) & 374 (99.2) \\
\hline Uruguay & $5(1.8)$ & $50(17.8)$ & $35(12.5)$ & $280(99.6)$ & $280(99.6)$ \\
\hline
\end{tabular}

${ }^{\prime} \mathrm{n}=616 ;{ }^{\dagger} \mathrm{n}=382 ;{ }^{\ddagger} \mathrm{n}=360 ;{ }^{\mathrm{s}} \mathrm{n}=269 ;{ }^{\prime \prime} \mathrm{n}=377 ;{ }^{\top} \mathrm{n}=281$.

Reported levels of psychological distress revealed that one third of the students $(33.5 \%)$ were experiencing moderate to severe psychological distress. Of these, only $8.8 \%$ had sought mental health treatment. Chi-square testing was conducted to investigate the relationship between childhood maltreatment and increased levels of psychological distress, with significant relationships observed in cases of sexual abuse $\left(X^{2}=25.65\right.$, $d f=3, \mathrm{n}=2264, \mathrm{p}<0.001)$ verbal abuse $\left(\mathrm{X}^{2}=133.48\right.$, $d f=3, \mathrm{n}=2272, \mathrm{p}<0.001)$, physical abuse $\left(X^{2}=90.13\right.$, $d f=3, \mathrm{n}=2269, \mathrm{p}<0.001)$ and neglect $\left(X^{2}=113.60\right.$, $d f=3, \mathrm{n}=2275, \mathrm{p}<0.001)$.

\section{Participant drug use}

Drug use within the past year and past 30 days was assessed among participants. More than half (52.1\%) reported using a psychoactive drug within the past year, with alcohol (48.2\%) and cannabis $(14.4 \%)$ being the most frequently used licit and illicit drugs, respectively. Table 3 illustrates rates of drug use among participants within the past 30 days.

Table 3 - Frequency of drug use within the past 30 days, by Country

\begin{tabular}{|c|c|c|c|c|c|c|c|c|}
\hline \multirow[b]{2}{*}{ Country } & \multicolumn{8}{|c|}{ Psychoactive Substance } \\
\hline & $\begin{array}{c}\text { Cannabis } \\
f(\%)\end{array}$ & $\begin{array}{c}\text { Tobacco/ } \\
\text { Cigarettes } \\
f(\%) \\
\end{array}$ & $\begin{array}{c}\text { Alcohol } \\
f(\%)\end{array}$ & $\begin{array}{c}\text { Cocaine } \\
F(\%)\end{array}$ & $\begin{array}{l}\text { Ecstasy } \\
f(\%)\end{array}$ & $\begin{array}{c}\text { Heroin } \\
f(\%)\end{array}$ & $\begin{array}{l}\text { Inhalants } \\
\quad f(\%)\end{array}$ & $\begin{array}{c}\text { Non-prescribed use of } \\
\text { prescription drugs } \\
f(\%) \\
\end{array}$ \\
\hline Colombia* $^{*}$ & 69 (11.2) & $169(27.4)$ & $342(55.5)$ & $11(1.8)$ & $3(0.5)$ & $2(0.3)$ & 7 (1.1) & $13(2.1)$ \\
\hline Jamaica $^{\dagger}$ & $18(4.7)$ & $24(6.3)$ & $92(24.1)$ & $3(0.8)$ & $3(0.8)$ & $3(0.8)$ & $7(1.8)$ & $7(1.8)$ \\
\hline Nicaragua $^{\ddagger}$ & $13(3.6)$ & $64(17.8)$ & $96(26.7)$ & $5(1.4)$ & $4(1.1)$ & $9(2.5)$ & $2(0.6)$ & $20(5.6)$ \\
\hline El Salvador ${ }^{\S}$ & $12(4.5)$ & $30(11.2)$ & $44(16.4)$ & $6(2.2)$ & $5(1.9)$ & $3(1.1)$ & $4(1.5)$ & $9(3.3)$ \\
\hline Panamall & $4(1.1)$ & $35(9.3)$ & 89 (23.6) & $2(0.5)$ & $2(0.5)$ & $2(0.5)$ & $6(1.6)$ & $21(5.6)$ \\
\hline Uruguay & $28(10.0)$ & $62(22.1)$ & $152(54.1)$ & $2(0.7)$ & $1(0.4)$ & $1(0.4)$ & $2(0.7)$ & $13(4.6)$ \\
\hline Total Sample $e^{* *}$ & $144(6.3)$ & $385(16.8)$ & $817(35.6)$ & $29(1.3)$ & $18(0.8)$ & $15(0.7)$ & $26(1.1)$ & $66(2.9)$ \\
\hline
\end{tabular}

${ }^{*} \mathrm{n}=616 ;{ }^{\dagger} \mathrm{n}=382 ;{ }^{\ddagger} \mathrm{n}=360 ;{ }^{\mathrm{n}} \mathrm{n}=269 ; "$ " $\mathrm{n}=377 ;{ }^{~} \mathrm{l} \mathrm{n}=281 ;{ }^{* *} \mathrm{n}=2,296$.

Of students drug users, $67.1 \%$ met the DSM IV criteria for substance abuse $(45.6 \%$ of males, $23.5 \%$ of females). Chi-square testing further revealed that these participants were more likely to have peers who also engaged in drug abuse $\left(X^{2}=\right.$ 247.69, $d f=1, \mathrm{n}=1747, \mathrm{p}<0.001)$.

\section{Relationship between childhood maltreat- ment and drug abuse}

Results indicated that participants who reported childhood maltreatment were more likely to abuse psychoactive drugs compared to those who were not exposed to any type of maltreatment 
$\left(\mathrm{X}^{2}=55.74, d f=1, \mathrm{n}=1,808, \mathrm{p}<0.001\right)$. In particular, physical abuse $\left(X^{2}=15.68, d f=1, n=1,806, p<0.001\right)$ and neglect $\left(X^{2}=99.76, d f=1, \mathrm{n}=1,811, \mathrm{p}<0.001\right)$ were significantly associated with later drug abuse.

\section{DISCUSSION}

Due to the widespread cultural acceptability of authoritarian parenting styles, only $14.9 \%$ of participants believed they were mistreated during childhood, yet $82.6 \%$ met the criteria for maltreatment. Although physical abuse was found to be common throughout the region, the most frequently reported type of maltreatment was neglect, which included a lack of resources required for medical treatment and/or meeting certain physical needs. This latter finding should be interpreted with caution given the harsh economic circumstances facing many communities across Latin America and the Caribbean. Acts of omission or commission that are typically considered to be neglect in high income nations may simply be the result of economic limitations in low income countries.

The current study identified an association between childhood maltreatment, increased levels of psychological distress in adulthood, and a greater likelihood of being diagnosed with a psychological disorder. This is anticipated to be the case even among cultural settings in which harsh parent disciplining techniques are more widespread and accepted. With this in mind, the relationship between maltreatment and adverse developmental outcomes does not appear to be linear. ${ }^{26}$ Although $82.6 \%$ met the criteria for childhood maltreatment, only one third of the participants reported moderate to severe psychological distress. Therefore, it would appear that not all cases of childhood maltreatment will result in increased levels of psychological distress or incidents of drug abuse.

Many factors have been identified in the relationship between childhood maltreatment and adult drug abuse, including peer and family relationships, religious beliefs, and mental health treatment. Depending on their presentation, these factors can serve as either protective or risk agents. Using a bioecological perspective ${ }^{27}$ Figure 1 presents a conceptual framework to clarify the relationship between childhood maltreatment and later drug abuse. A cohesive and supportive family unit, ${ }^{28}$ association with non-drug using peers, ${ }^{29}$ strong religious beliefs, ${ }^{30}$ and access to psychological aid are considered protective factors against drug abuse. On the other hand, childhood maltreatment, psychological distress in adulthood, lack of psychological treatment, and association with drug abusers are all risk factors for drug use and abuse.

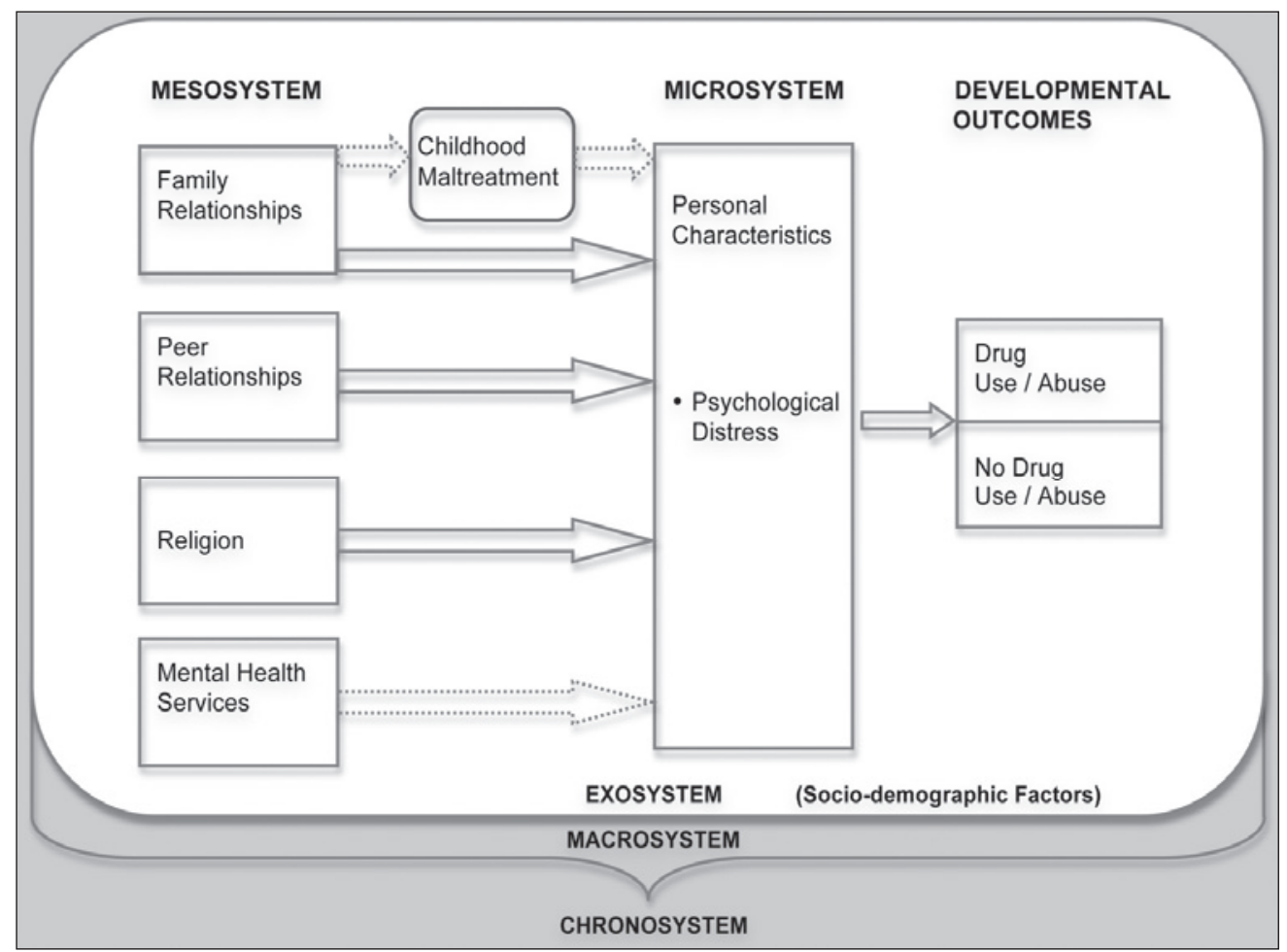

Figure 1 - Conceptual framework of the relationship between experiencing maltreatment during childhood and later drug abuse, 2011 


\section{CONCLUSIONS}

This study found that being exposed to maltreatment during childhood may result in higher levels of psychological distress during adulthood, among select Latin American and Caribbean university students. It was also identified that experiencing maltreatment during childhood is a potential precursor to adult drug abuse. Of note, the adverse effects associated with experiencing maltreatment during childhood, may occur even when the victims lack the awareness that they had been maltreated.

\section{Limitations}

The study is limited by the involvement of only one university from one country in the Caribbean and only six universities from five countries in Latin America. This limitation derives from the reality of 34 countries and several hundred universities in Latin America and the Caribbean. Although random sampling was the desired sampling technique, it was not possible for one of the selected institutions involved in the study. Therefore, the data is seen as being obtained through non-probability sampling, which limits the generalizability of the results. Further, results based on retrospective data should be interpreted with caution given the possibility of poor recollection among participants, or increased likelihood of the deliberate under-or over-reporting on sensitive topics such as those addressed in the current study.

\section{Recommendations}

This study supports other research from Canada and the United States indicating that childhood neglect and maltreatment are important risk factors for drug abuse later in life and indicates that the same may be true in Latin American and Caribbean countries. Universities participating in the study may be well advised to broaden their drug abuse prevention strategies to incorporate policies and interventions aimed at childhood maltreatment. One approach could be educational campaigns informing the university's population about the adverse effects of maltreatment, including the harmful consequences of drug abuse. It is also recommended that drug abuse treatment facilities, serving the respective universities' populations, screen participants for exposure to childhood maltreatment and, where necessary, include psychotherapeutic treatments to ameliorate any adverse impact.

\section{ACKNOWLEDGEMENT}

The Organization of America States (OAS), the Inter-American Drug Control Commission (CICAD), the Government of Canada/DFAIT, and the Centre for Addiction and Mental Health $(\mathrm{CAMH})$, Toronto-Canada for supporting and endorsing this project financially and technically; to the selected Universities in Latin America and the Caribbean for their invaluable support; as well as other collaborators and the students who participated in the research.

\section{REFERENCES}

1. Longman-Mills S, González Y, Meléndez M, García M, Gómez J, Juárez C, et al. Child maltreatment and Its relationship to drug use in Latin America and the Caribbean: an overview and multinational research partnership. Int J Mental Health Addiction. 2011; 9(4):347-64.

2. Madhani A. Colombia no longer top cocaine producer. The Oval: USA Today; 2012.

3. Rohsenow DJ, Corbett R, Devine D. Molested as children: a hidden contribution to drug abuse? J Subst Abuse Treat. 1988;5(1):13-8.

4. Medrano MA, Zule WA, Hatch J, Desmond DP. Prevalence of childhood trauma in a community sample of drug-abusing women. Am J Drug Alcohol Abuse. 1999; 25:449-62.

5. Leventhal AM, Schmitz JM. The role of drug use outcome expectancies in drug abuse risk: an interactional-transformational model. Addict Behav. 2006; 31:2038-62.

6. Adlaf EM, Smart RG. Drug use and religious affiliation, feelings and behaviour. British J Addict. 1985; 80(2):163-71.

7. Hartzler B, Fromme K. Cognitive-behavioral profiles of college risk-takers with type II and psychopathic personality traits. Addict Behav. 2003; 28(2):315-26.

8. Johnson LD, O'Malley PM. Why do the nation's students use drugs and alcohol? Self reported reasons from nine national surveys. J Drug Issues. 1986; 16:29-66.

9. Leeb R, Paulozzi L, Melanson C, Simon T, Arias I. Child maltreatment surveillance: uniform definitions for public health and recommended data elements, version 1.0. Atlanta (US); 2008.

10. Righthand S, Kerr B, Drach K. Child maltreatment risk assessments: an evaluation guide. binghampton. New York: (US) The Haworth Maltreatment and Trauma Press; 2003.

11. Becker-Weidman A. Effects of eary maltreatment on development: a descriptive study using the vineland adaptive behaviour scales-II. Child Welfare . 2009; 88(2):137-61. 
12. Yoast R, McIntyre K. Alcohol, other drug abuse and child abuse and Neglect. Madison (US): Wisconsin Clearinghouse; 1991.

13. United Nations (UN) [web page]. Economic commission for Latin America and the Caribbean (ECLAC), United Nations Children's Fund (UNICEF). Child abuse: A painful reality behind closed doors. 2009 [cited 2010 August 16]; Available from: http://www.eclac.org/dds/noticias/ desafios/0/37890/Challenges9-cepal-unicef.pdf

14. Defensoría del Pueblo [web page]. Resolucion defensorial humanitaria n. 008. 2001 [cited 2013 Sep 29]; Available from: http://www.defensoria.org. $\mathrm{co} / \mathrm{pdf} /$ resoluciones/humanitaria/humanitaria8. pdf

15. Institute de Medicina Legal y Ciencia Forenses [web page]. División de referencia de información pericial DRIPE stadisticas. 2000 [cited 2013 Sep 29]; Available from: http://www.medicinalegal.gov.co/index. php?option=com

16. Speizer I, Goodwin M, Samandari G, Kim S, Clyde M. Dimensions of child punishment in two Central American countries: Guatemala and El Salvador. Rev Panam Salud Pública. 2008; 23(4):247-56.

17. Office of the Children's Registry [web page]. Statistics by type of abuse. 2012 [cited 2012 July 30]; Available from: http:/ / www.ocr.gov.jm/Child $\% 20$ abuse $\% 20$ stats.html

18. Gutierrez Herrera E. Broken angels. La pensa the diary of the nicaraguan, 2009 Nov 18.

19. Panama Government National Plan of Action of the Childhood and the Adolescence. National Plan of Action of the Childhood and the Adolescence. In: Government P, editor. Panama (PA): Panama Government; 2007.

20. De los Campos H, Solari M, González M. Prevalencia del maltrato intra familiar contra niños y adolescentes. Prácticas de crianza y resolución de conflictos familiares [internet]. 2008 [cited 2010 July 15]; Available from: http:/ / www.infamilia.gub.uy/ gxpsites/hgxpp001.aspx.
21. Rothman EF, Edwards EM, Heeren T, Hingson RW. Adverse childhood experiences predict earlier age of drinking onset: results from a representative US sample of current or former drinkers. Pediatrics. 2008; 122(2):298-304.

22. Kessler R, Barker P, Colpe L, Epstein J, Gfroerer J, Hiripi E, et al. Screening for serious mental illness in the general population. Archives General Psychiatry. 2003; 60(2):184-9.

23. Organisation of American States I-ADACC. Comparative analysis of student drug use in Caribbean countries. Washington (US): Organisation of American States; 2010.

24. Centers for Disease Control and Prevention [online]. Adverse Childhood Experiences (ACE) Study. 2012 June 1, 2011 [cited 2012 Aug 22]; Available from: www.cdc.gov/ace/questionnaires.htm

25. Pratt L. Characteristics of adults with serious psychological distress as measured by the K6 Scale: United States 2001-04. Adv Data. 2007 Mar; 382:1-18

26. Mrazek PJ, Mrazek DA. Resilience in child maltreatment victims: a conceptual exploration. Child Abuse Negl. 1987; 11(3):357-66.

27. Bronfenbrenner U. The bioecological model of human development. In: Bronfenbrenner U, editor. Making human beings human: bioecological perspectives on human development. Thousand Oaks, California (US): Sage Publications; 2005. p. 3-15.

28. Matthew I, Pillon S. Protection factores and risks associated with alcohol use in adolescents with alcohol-addicted parents in Peru. Rev Latino-Am Enferm. 2004; 12:359-68.

29. Rodriquez GM, Luis Villar MA. Descriptive study of drug use among adolescents in higher middle education in Monterrey, Nuevo Leon, Mexico. Rev Latino-Am Enferm. 2004; 12: 391-7.

30. Doxey C, Jensen L, Jensen J. The Influence of religion on victims of childhood sexual abuse. International Journal for the Psychology of Religion. 1997; 7(3):179. 